\title{
Recording Thirteen New Species of Phytoplankton in Euphrates River Environment in Iraq
}

\author{
Huda Abdullah ALI ${ }^{1, *}$, Mustafa Nadhim OWAID ${ }^{2,3}$ and Shaimaa Fatih ALI ${ }^{4}$ \\ ${ }^{I}$ Department of Hadithah Education, General Directorate of Education in Anbar, Ministry of Education, \\ Anbar, Iraq \\ ${ }^{2}$ Department of Heet Education, General Directorate of Education in Anbar, Ministry of Education, \\ Anbar, Iraq \\ ${ }^{3}$ Department of Environmental Sciences, College of Applied Sciences, University of Anbar, Anbar, Iraq \\ ${ }^{4}$ Department of Biology, College of Science, Tikrit University, Tikrit, Iraq
}

('Corresponding author's e-mail: huda.abdullah2018@gmail.com)

Received: 24 November 2018, Revised: 3 May 2019, Accepted: 18 June 2019

\begin{abstract}
Thirteen species of phytoplankton were recorded for the first time in the Upper Euphrates River environment in Iraq during the period from January to June 2017. Five locations were selected along the river (Jubba village, Al-Baghdadi district, Dollab village, Hit city and Ramadi city). Among the 13 taxa, seven species belonging to the Chlorophyta division were identified: Excentrosphaera viridis, Monoraphidium caribeum, Nephrochlamys willeana, Oonephris palustris, Staurodesmus cuspidatus, Palmodictyon varium, and Westellopsis linearis. Moreover, two species of the Chrysohyta division, Rhizochrysis limnetica and Chrysidiastrum catenatum, were recorded in the study area. Two species belonging to the Bacillariophyta division were Acanthoceras zachariasii and Stenopterobia intermedia, showing in the study area. One species belonging to the Cyanophyta division, Stichosiphon sansibaricus, was recorded in Hit and Ramadi, and one species of Euglenophyta (Phacus orbicularis) was also recorded. Some physicochemical properties of the water from these locations were measured, including water temperature values ranging from $8-13{ }^{\circ} \mathrm{C}$; $\mathrm{pH}$ ranging from 7.22 - 7.58; EC ranging from 580 $755 \mu \mathrm{S} . \mathrm{cm}^{-1}$, while salinity was $0.30-0.44$ g.L. $\mathrm{L}^{-1}$. Nutrient, such as nitrates, and phosphate values ranged from $156-232 \mu \mathrm{g} . \mathrm{L}^{-1}$ and $8.21-21 \mu \mathrm{g} . \mathrm{L}^{-1}$, respectively. The presence of new phytoplankton in Iraqi freshwater confirms the quality of river water in this area. This study was carried out to contribute to the knowledge of freshwater phytoplankton in Iraq for the upper region of the Euphrates River and their tributaries.
\end{abstract}

Keywords: Biodiversity, Euphrates River, freshwater, microalgae, phytoplankton

\section{Introduction}

River ecosystems are under threat from various human activities, leading to considerable changes in sediment delivery and flow patterns, decreasing water quality, and loss of biodiversity [1]. The Euphrates River is the longest river in West Asia, and has a length of approx. $2940 \mathrm{~km}$. Also, new phytoplankton species have been recorded in the last years, to add new knowledge to data on biota in Iraq. Iraqi algologists have studied various habitats to collect and identify various phytoplankton in numerous Iraqi aquatic ecosystems, such as rivers, their tributaries, and marshlands [2].

Algae are an essential part of the food chain in water, because they reflect the health of their environment through their distribution, abundance, and productivity. Algae are primary products in many aquatic systems, as they are one of the primary sources of fish food, larvae, and other aquatic organisms $[3,4]$. Phytoplankton algae communities have rapid responses to water disturbance, as water pollution 
http://wjst.wu.ac.th

often changes the composition of species or diversity [5]. Recently, algae have been used as healthy foods, bioenergy, organic fertilizers for plants, and for producing antibiotics like the biosynthesis of silver nanoparticles, which is considered as a nano-drug against human pathogenic microbes [6].

Algae can grow in different locations and can be distributed in any ecosystem [7]. Many authors and researchers have attempted to complete a list of algae in Iraq. A few checklists have been published, and the recording of new phytoplankton in the aquatic ecosystems in Iraq has been conducted by many researchers [8-11].

A few studies of phytoplankton in the Euphrates River were conducted by Hassan et al. [12], Aldaraji [13], and Al-Gaff [14], thus, the present study aimed to study algal species and add new records of species of phytoplankton for the first time in the environment of the Euphrates River of Iraq.

\section{Materials and methods}

\section{Location of the study}

Five locations were selected on the Euphrates River for collecting samples from the sides of the river in this study. The samples were collected monthly during the period from January to June 2017 (Figure 1 and Table 1). The geographical coordinates of the study location were determined using GPS (Global Positioning System, Italy), as shown in Figure 1. The study area was surrounded by agricultural fields on both sides of the river.

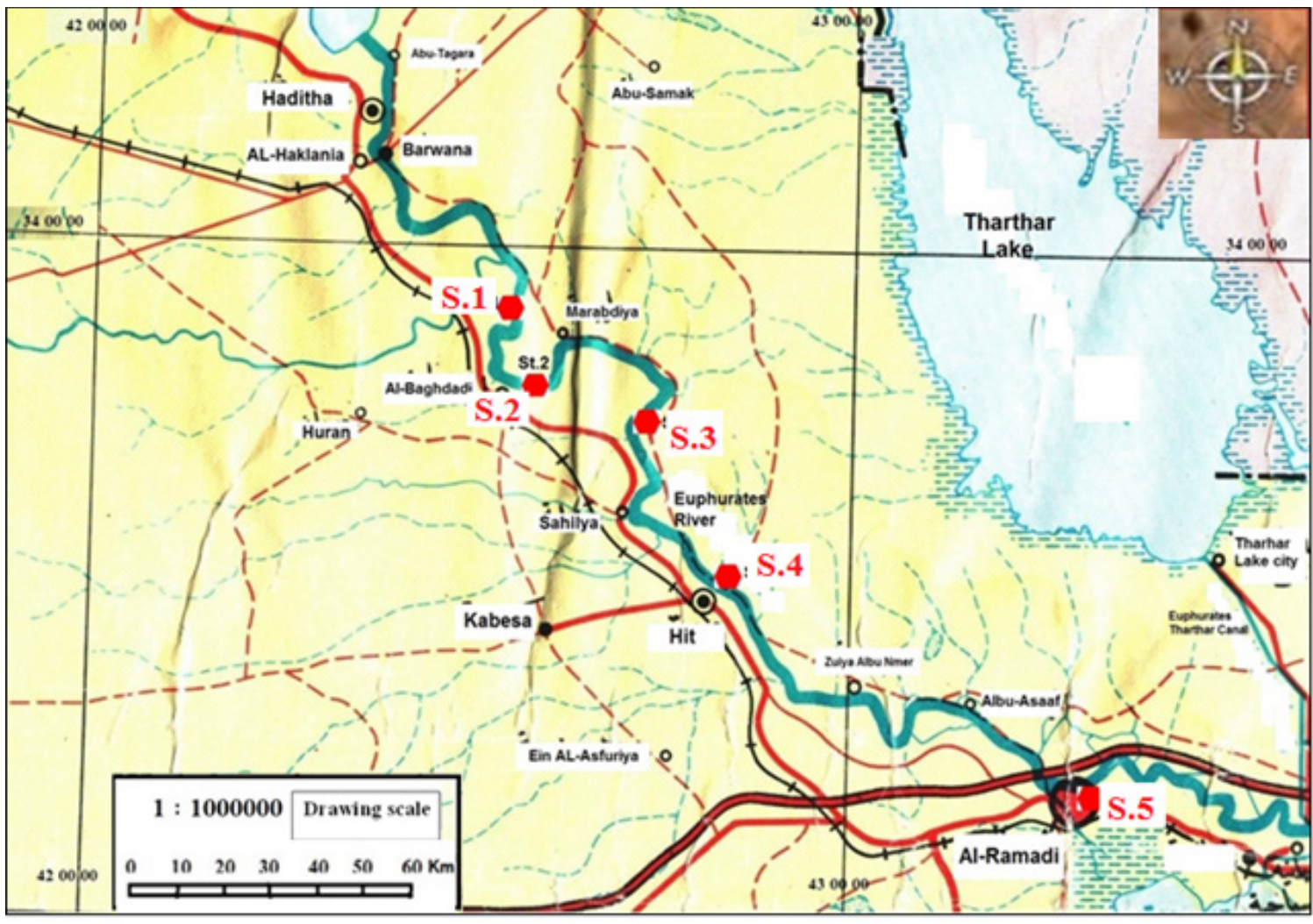

Figure 1 Map of the study area with locations of samples on the Euphrates River 
http://wjst.wu.ac.th

Table 1 Geographical coordinates (GPS) of the five study locations

\begin{tabular}{ccclll}
\hline Symbols of Locations & Name of Locations & \multicolumn{2}{c}{ Longitude (eastwards) } & \multicolumn{2}{c}{ Latitudes (northward) } \\
\hline Location 1 & Jubba village & $42^{\circ} 33^{\prime} 17.18$ & $\mathrm{E}$ & $33^{\circ} 54^{\prime} 19.91^{\prime}$ & $\mathrm{N}$ \\
Location 2 & Al-Baghdadi district & $42^{\circ} 32^{\prime} 4.28^{\prime}$ & $\mathrm{E}$ & $33^{\circ} 53^{\prime} 14.29^{\prime}$ & $\mathrm{N}$ \\
Location 3 & Dollab village & $42^{\circ} 45^{\prime} 3.00^{\prime}$ & $\mathrm{E}$ & $33^{\circ} 49^{\prime} 52.62^{\prime}$ & $\mathrm{N}$ \\
Location 4 & Hit city & $42^{\circ} 49^{\prime} 4.90^{\prime}$ & $\mathrm{E}$ & $33^{\circ} 39^{\prime} 3.16^{\prime}$ & $\mathrm{N}$ \\
Location 5 & Ramadi city & $43^{\circ} 15^{\prime} 34.27^{\prime}$ & $\mathrm{E}$ & $33^{\circ} 26^{\prime} 24.49^{\prime}$ & $\mathrm{N}$ \\
\hline
\end{tabular}

\section{Physiochemical properties of water}

Water temperature was measured immediately in the field using a mercury thermometer. The electrical conductivity (EC), salinity and $\mathrm{pH}$ (concentration of hydrogen ions) were measured using a $\mathrm{pH}$, EC, and Salinity meter (HANNA Instruments). Concentrations of nitrates $\left(\mathrm{NO}_{3}\right)$ and phosphates $\left(\mathrm{PO}_{4}\right)$ in the water were determined according to APHA [15].

\section{Collection and identification of phytoplankton}

Several vertical hauls in each location were made for collecting phytoplankton using a Phytoplankton net (mesh of $20 \mu \mathrm{m}$ ). Phytoplankton samples were placed in polyethylene containers and preserved by adding a few drops of Lugol's iodine solution. Clarification of diatoms was achieved using absolute nitric acid, as in the methods described by Salman et al. [16] and Hadi [17]. The phytoplankton were identified depending on the following references for identification of non-diatomic algae [18-22] and photographed using a compound Olympus microscope with a camera. The identified taxa of the present study was checked using the checklist of Maulood and Toma [23], Hadi et al. [24], and Bahram et al. [25], and then determined as new taxa for Iraqi algal flora.

\section{Results and discussion}

In the present study, the measured physicochemical parameters are shown in Table 2. Water temperature ranged from 8 to $13{ }^{\circ} \mathrm{C}$. Temperature is an important factor, and affects the solubility of gases and salts in water. Thus, it affected the behavior, physiology, and distribution of aquatic organisms [26]. The $\mathrm{pH}$ values ranged from 7.22 to 7.58 , and many studies have recorded the buffer capacity of Iraqi inland water, such as [12,27-29] and, thus, is suitable for living organisms like phytoplankton. Also, the values of $\mathrm{pH}$ of water belonging to $\mathrm{CaCO}_{3}$ in sedimentations of inflows are in agreement with the results of [30]. It plays an essential role in the chemical and biological balances of water [23]. Salinity ranged from $0.30-0.44$ g. $\mathrm{L}^{-1}$ from location 1 to 4 ; these results revealed that the river water was fresh, according to the classification of Reid [31]. EC values ranged from 580 to $755 \mu \mathrm{S}^{-\mathrm{cm}^{-1}}$. Nitrogen and phosphorous are two major essential nutrients for algae growth [32]. During the study period, values of nitrates and phosphates were elevated at all locations, interpreted as increasing human activity in agriculture and sewage wastes which discharge into the study sites without any treatment. Moreover, the chemical changes in the river's water changed the numbers and species of organisms in habitats, including phytoplankton. The differences between the amounts and types of pollutants discharged onto the surface affects the physical, chemical, and biological properties of water [33]. 
http://wjst.wu.ac.th

Table 2 Mean value for physicochemical parameters in Euphrates river during the study period

\begin{tabular}{lccccc}
\hline \multirow{2}{*}{ Parameters } & \multicolumn{5}{c}{ Sites of the study } \\
\cline { 2 - 6 } & Location 1 & Location 2 & Location 3 & Location 4 & Location 5 \\
\hline Water Temp. ${ }^{\circ} \mathrm{C}$ & 11 & 8 & 10 & 13 & 12 \\
$\mathrm{pH}$ & 7.22 & 7.50 & 7.42 & 7.52 & 7.58 \\
$\mathrm{EC} \mu \mathrm{S} . \mathrm{cm}^{-2}$ & 637 & 580 & 692 & 755 & 724 \\
Salinity gm.L ${ }^{-1}$ & 0.30 & 0.39 & 0.38 & 0.44 & 0.41 \\
Nitrate $\mu \mathrm{g} . \mathrm{L}^{-1}$ & 183 & 177 & 165 & 203 & 232 \\
Phosphate $\mu \mathrm{g} . \mathrm{L}^{-1}$ & 13.1 & 8.21 & 17 & 12.6 & 21 \\
\hline
\end{tabular}

Physicochemical parameters of water contribute to biodiversity because phytoplankton is sensitive to environmental variations. For this reason, physicochemical parameters have been commented on as being important for the existence or disappearance of some organisms and can show long-term changes in water quality [34]. High nitrate-nitrogen concentrations are related to shallow groundwater [35] and high nitrate concentration in river water is mainly from irrigation runoff from agriculture fields, where chemical fertilizers have been used intensively. Excess nutrients cause a massive increase in the growth of algae or plankton and overwhelms huge areas of the river. As a result, the watercourse is choked with organic substances and organisms. Consequently, the water becomes deficient of oxygen, which affects aquatic life [35]. The quality of water in the Euphrates River in this zone is clean, in agreement with some local studies of this river by Ali and Al-Mahdawi [9]. This helps biodiversity in this habitat and the appearance of new algal species.

There is strong variation in the correlations between the collected phytoplankton and water quality indices, suggesting that the limiting factor for this phytoplankton growth depends on seasonality and location, and it is necessary to reduce both nitrogen and phosphorus inputs. Water temperature is another important controlling factor for algal growth. Using principal component analysis is considered a key driving factor for water quality problems [36].

Table 3 shows lists of the recorded algal taxa, followed by a description of the identified species. Thirteen species of phytoplankton were identified in this study within the Euphrates River (Figure 1) for the first time in the Iraqi aquatic environment; 7 Chlorophyta, 2 Chrysophyta, 2 Bacillariophyta, 1 Cyanophyta, and 1 Euglenophyta (Figures 2 and 3).

Table 3 New algal recorded within the study sites

\begin{tabular}{|c|c|c|c|c|c|c|}
\hline \multirow[b]{2}{*}{ List of algal taxa } & \multirow{2}{*}{$\begin{array}{l}\text { Month of } \\
\text { collection }\end{array}$} & \multicolumn{5}{|c|}{ Study Locations } \\
\hline & & $\begin{array}{l}\text { Loc. } 1 \\
\text { Jubba }\end{array}$ & $\begin{array}{c}\text { Loc. } 2 \\
\text { Al-Baghdadi }\end{array}$ & $\begin{array}{r}\text { Loc. } 3 \\
\text { Dollab }\end{array}$ & $\begin{array}{c}\text { Loc. } 4 \\
\text { Hit }\end{array}$ & $\begin{array}{c}\text { Loc.5 } \\
\text { Ramadi }\end{array}$ \\
\hline \multicolumn{7}{|l|}{ CHLOROPHYCEAE } \\
\hline Excentrosphaera viridis & March & & $*$ & & & \\
\hline Monoraphidium caribeum & March & & & * & $*$ & \\
\hline Nephrochlamys willeana & April & & & & & $*$ \\
\hline Oonephris palustris & March & & & & $*$ & \\
\hline Staurodesmus cuspidatus & May & $*$ & & & & \\
\hline Palmodictyon varium & February & & & $*$ & & \\
\hline Westellopsis linearis & April & $*$ & & & & \\
\hline \multicolumn{7}{|l|}{ CHRYSOPHYACEA } \\
\hline Rhizochry limnetica & January & $*$ & & & & \\
\hline
\end{tabular}




\begin{tabular}{|c|c|c|c|c|c|c|}
\hline \multirow[b]{2}{*}{ List of algal taxa } & \multirow{2}{*}{$\begin{array}{l}\text { Month of } \\
\text { collection }\end{array}$} & \multicolumn{5}{|c|}{ Study Locations } \\
\hline & & $\begin{array}{l}\text { Loc. } 1 \\
\text { Jubba }\end{array}$ & $\begin{array}{c}\text { Loc. } 2 \\
\text { Al-Baghdadi }\end{array}$ & $\begin{array}{r}\text { Loc. } 3 \\
\text { Dollab } \\
\end{array}$ & $\begin{array}{c}\text { Loc. } 4 \\
\text { Hit }\end{array}$ & $\begin{array}{c}\text { Loc.5 } \\
\text { Ramadi }\end{array}$ \\
\hline Chrysidiastrum catenatum & May & & & & $*$ & \\
\hline \multicolumn{7}{|l|}{ BACILLARIOPHYCEAE } \\
\hline Acanthoceras zachariasii & February & & * & & & \\
\hline Stenopterobia intermedia & January & & & $*$ & & \\
\hline \multicolumn{7}{|l|}{ CYANOPHYCEAE } \\
\hline Stichosiphon sansibaricus & June & & & & $*$ & $*$ \\
\hline \multicolumn{7}{|l|}{ EUGLENOPHYCEAE } \\
\hline Phacus orbicularis & June & & & * & & \\
\hline
\end{tabular}

The following is a description of the identified phytoplankton in this study:

\section{Excentrosphaera viridis}

Division: Chlorophyta

Class: Chlorophyceae

Order: Chlorococcales

Family: Oocystaceae

Genus: Excentrosphaera

Species: Excentrosphaera viridis G.T.Moore 1901 (Figures 2a and 2b)

E. viridis is unicellular and spherical. The characteristic feature of this genus is $20-60 \mu \mathrm{m}$ cell diameter. Tychoplankter is located in shallow water of lake margins and acid swamps or soft water marshes. E. viridis was found at location 1 in March 2017.

\section{Monoraphidium caribeum}

Division: Chlorophyta

Class: Chlorophyceae

Order: Sphaeropleales

Family: Chlorellaceae

Genus: Monoraphidium

Species: Monoraphidium caribeum Hindák 1970 (Figure 2c)

Cells are solitary, arched into a semicircle, slightly sigmoidal curved to the ends, attenuated and sharply pointed. Cells have parietal chloroplasts, trough-shaped without pyrenoid. Its reproduction is by 2 - 4 autospores. Dimensions: cell is $1.0-2.4(3.6 \mu \mathrm{m})$, the distance between the ends $9.6-26.4(35 \mu \mathrm{m})$. M. caribeum was found at locations 3 and 4 in March 2017.

\section{Nephrochlamys willeana}

Division: Chlorophyta

Class: Trebouxiophyceae

Order: Oocystales

Family: Oocystaceae

Genus: Nephrochlamys

Species: Nephrochlamys willeana (Printz) Korshikov 1953 (Figures 2d and 2e)

Solitary cells, rarely colonies with 2 or 4 cells-mother cell walls, have the shape of cells, kidney or rounded, enlarged, hyaline, firm, with visible thickenings at the poles. They have kidney cells with 
http://wjst.wu.ac.th

thickened ends of old cells. The cells contain one parietal chloroplast at a convex side of the cell, without visible pyrenoid. Reproduction is by 2 - 4 autospores, which sometimes remain in the mother-wall or are liberated through the dorsal opening. Dimensions of $N$. willeana are $4.5-11.5 \times 3.0-5.5 \mu \mathrm{m}$, and the species was collected from location 5 in April 2017.

\section{Oonephris palustris}

Division: Chlorophyta

Class: Trebouxiophyceae

Order: Oocystales

Family: Oocystaceae

Genus: Oonephris

Species: Oonephris palustris Komárek 1983 (Figure 2f) [18-22]

Cells are regular, narrow to wide oval, and thickened to the poles, with visible pores in the polar thickening. They live solitarily or in 4 to 8 celled colonies. The cell wall is thick and composed from 3 layers (or more), finely laminated. They have a central chloroplast (spongiomorph), with a distinct central pyrenoid. O. palustris was collected from location 4 in March 2017.

\section{Staurodesmus cuspidatus}

Division: Streptophyta

Class: Zygnematophyceae

Order: Zygnematales

Family: Desmidiaceae

Genus: Staurodesmus

Species: Staurodesmus cuspidatus (Bréb.) Teiling 1967 (Figure 2g) [18-22]

Length of Staurodesmus cuspidatus is about $38-53 \mu \mathrm{m}$, and its width is about $24-43 \mu \mathrm{m}$. $S$. cuspidatus was found at location 1 in May 2017.

\section{Palmodictyon varium}

Division: Chlorophyta

Class: Chlorophyceae

Order: Tetrasporales

Family: Palmellaceae

Genus: Palmodictyon

Species: Palmodictyon varium (Nägeli) Lemmermann 1915 (Figure 2h) [18-22]

Thallus is more than one branch and gelatinous strand or cylinder anastomosing in which families of globose cells are staged in groups of 2 - 4 within a mucilaginous sheath. Cells are arranged in 1 or 2 linear series, sometimes with a distinct lamellar sheath. Size of the cell is $5-10 \mu \mathrm{m}$ in diameter, thallus; $15-20$ $\mu \mathrm{m}$ in wide. This microalgal species was found at location 3 in February 2017.

\section{Westellopsis linearis}

Division: Chlorophyta

Class: Chlorophyceae

Order: Sphaeropleales

Family: Scenedesmaceae

Genus: Westellopsis

Species: Westellopsis linearis (G.M.Smith) C.C.Jao (Figures $\mathbf{2 i}$ and $\mathbf{2 j}$ ) [18-22] 
http://wjst.wu.ac.th

Colonies of $W$. linearis have an irregular shape. Nearly 40 globular cells are coordinated in 4 serial linear groups. Fragment residues of mother cell walls hold the cells. The diameter of the cell is $2-5 \mu \mathrm{m}$. Colonies of $W$. linearis were found at location 1 in April 2017.

Rhizochrysis limnetica

Division: Chrysophyta

Class: Chrysophyceae

Order: Rhizochrysidales

Family: Rhizochrysidaceae

Genus: Rhizochrysis

Species: Rhizochrysis limnetica G.M.Smith 1920 (Figure 2k) [18-22]

Cells of Rhizochrysis limnetica are floating algae, irregular globose with radial plaques, needle pseudopodial processes: one golden chromatophore, numerous vacuoles. Cell diameter is $40 \mu \mathrm{m}$ without processes. It was found at location 1 in January 2017.

Chrysidiastrum catenatum

Division: Chrysophyta

Class: Chrysophyceae

Order: Rhizochrysidales

Family: Rhizochrysidaceae

Genus: Chrysidiastrum

Species: Chrysidiastrum catenatum Lauterborn 1913 (Figure 21) [18-22]

Cell of golden color globose, $12-15 \mu \mathrm{m}$ in diameter without processes, 45 - $60 \mu \mathrm{m}$ wide including processes. This species was found at location 4 in May 2017. 

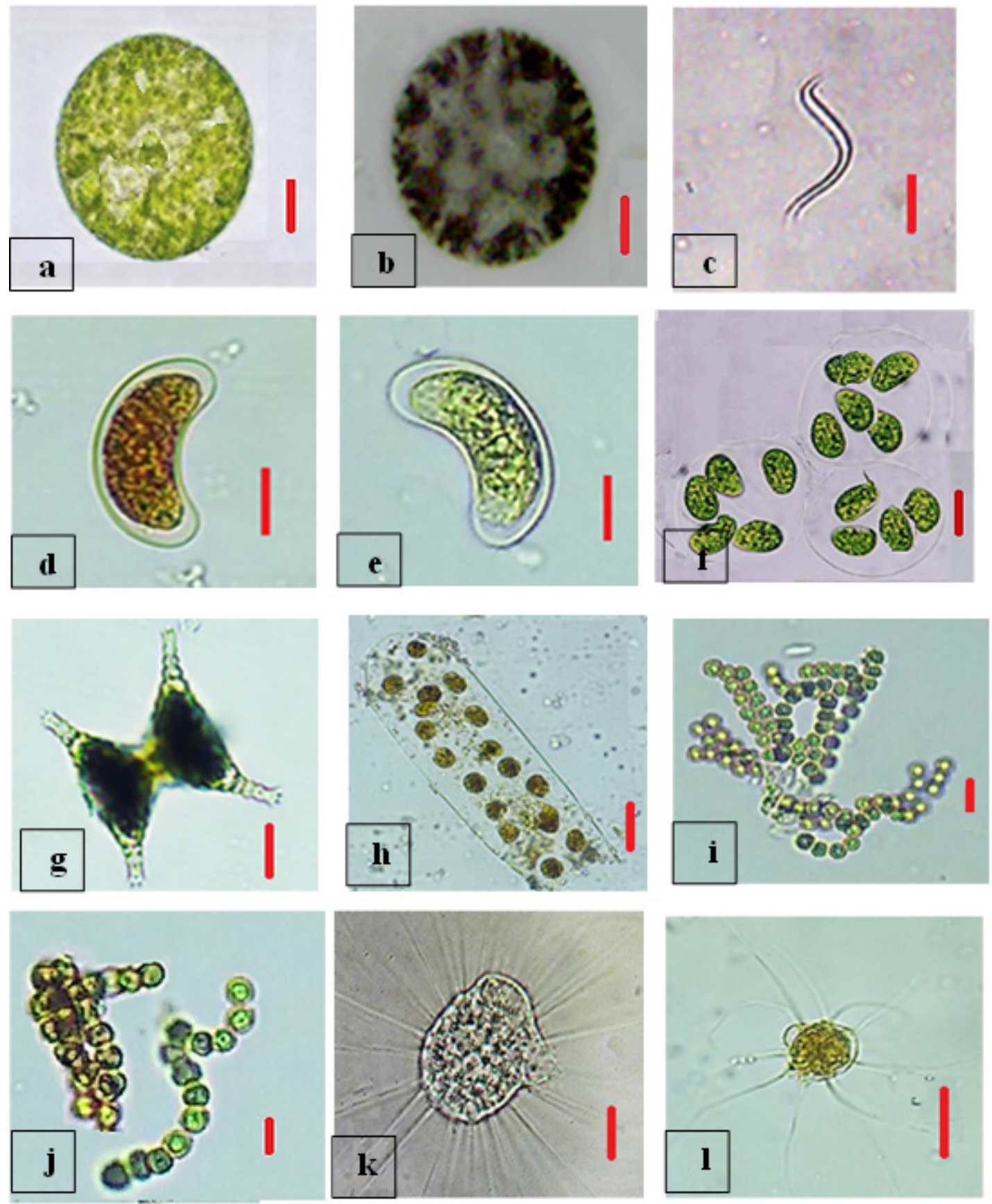

Figure 2 Some of the recorded species (a, b: Excentrosphaera viridis; c: Monoraphidium caribeum; d, e: Nephrochlamys willeana; f: Oonephris palustris; g: Staurodesmus cuspidatus; h: Palmodictyon varium; i, $\mathrm{j}$ : Westellopsis linearis; $\mathrm{k}$ : Rhizochry limnetica; 1 : Chrysidiastrum catenatum $)($ Red scale bar $=10 \mu \mathrm{m})$ 
http://wjst.wu.ac.th

\section{Acanthoceras zachariasii}

Division: Bacillariophyta

Class: Mediophyceae

Order: Chaetocerotales

Family: Acanthocerataceae

Genus: Acanthoceras

Species: Acanthoceras zachariasii (Brun) Simonsen 1979 (Figures 3a and 3b) [18-22]

This new denomination is justified by the very different structure of Attheya decora west marine species, which remains alone in this monospecific species, belonging to the Biddulphiaceae family and returning to Acanthoceras zachariasii, family Chaetoceraceae. It is a rare species in the region, where it appears sporadically. It develops abundantly about 30 to $60 \mu \mathrm{m}$ long and 15 to $45 \mu \mathrm{m}$ wide. A. zachariasii was found at location 2 in February 2017.

\section{Stenopterobia intermedia}

Division: Bacillariophyta

Class: Bacillariophyceae

Subclass: Bacillariophycidae

Order: Surirellales

Family: Surirellaceae

Genus: Stenopterobia

Species: Stenopterobia intermedia (F.W.Lewis) Van Heurck ex Hanna 1933 (Figure 3c) [18-22]

The valve of $S$. intermedia is very long, ranging from 120 to $350 \mu \mathrm{m}$, narrow 6 to 10 wide, streaks 4 to $5.5 \mathrm{in} 10 \mu \mathrm{m}$. The transverse striae are fine and variable, 19 to 23 in $10 \mu \mathrm{m}$. This species was found at location 3 in January 2017.

\section{Stichosiphon sansibaricus}

Division: Cyanophyta

Class: Cyanophyceae

Subclass: Oscillatoriophycidae

Order: Chroococcales

Family: Stichosiphonaceae

Genus: Stichosiphon

Species: Stichosiphon sansibaricus (Hieronymus) F.E.Drouet and W.A.Daily 1956 (Figure 3d) [18-22]

The cell of $S$. sansibaricus occurs singly or in groups, attached to a substrate at their narrow base. Its cells produce endospores (sometimes called exospores or exocytes), asexual reproductive cells that bud from the parent cell. The endospores remain inside the sheath, giving the manifestation of a uniseriate filament. The sheath is open at the unattached end, through which exospores will eventually exit. Generally, the common species, $S$. sansibaricus, disperse pantropically and also in the temperate zone. The species is located in basins of thermal and tropical water plants. Moreover, in this study, it was found at locations 4 and 5 in June 2017.

\section{Phacus orbicularis}

Division: Euglenophyta

Class: Euglenophyceae

Order: Euglenales

Family: Euglenaceae

Genus: Phacus

Species: Phacus orbicularis K.Hübner (Figure 3e) [18-22] 
http://wjst.wu.ac.th

Mostly, the cell is ovoid and arranged in a long or short caucus. Anteriorly, broadly rounded but slightly bilobed because of the gullet groove; periplast longitudinally striated; margin of the cell with 2 - 3 bulges; large centrally located paramylon disc, the diameter of cells in $65-65 \mu \mathrm{m}, 80-100 \mu \mathrm{m}$ long. It was found at location 3 in June 2017.
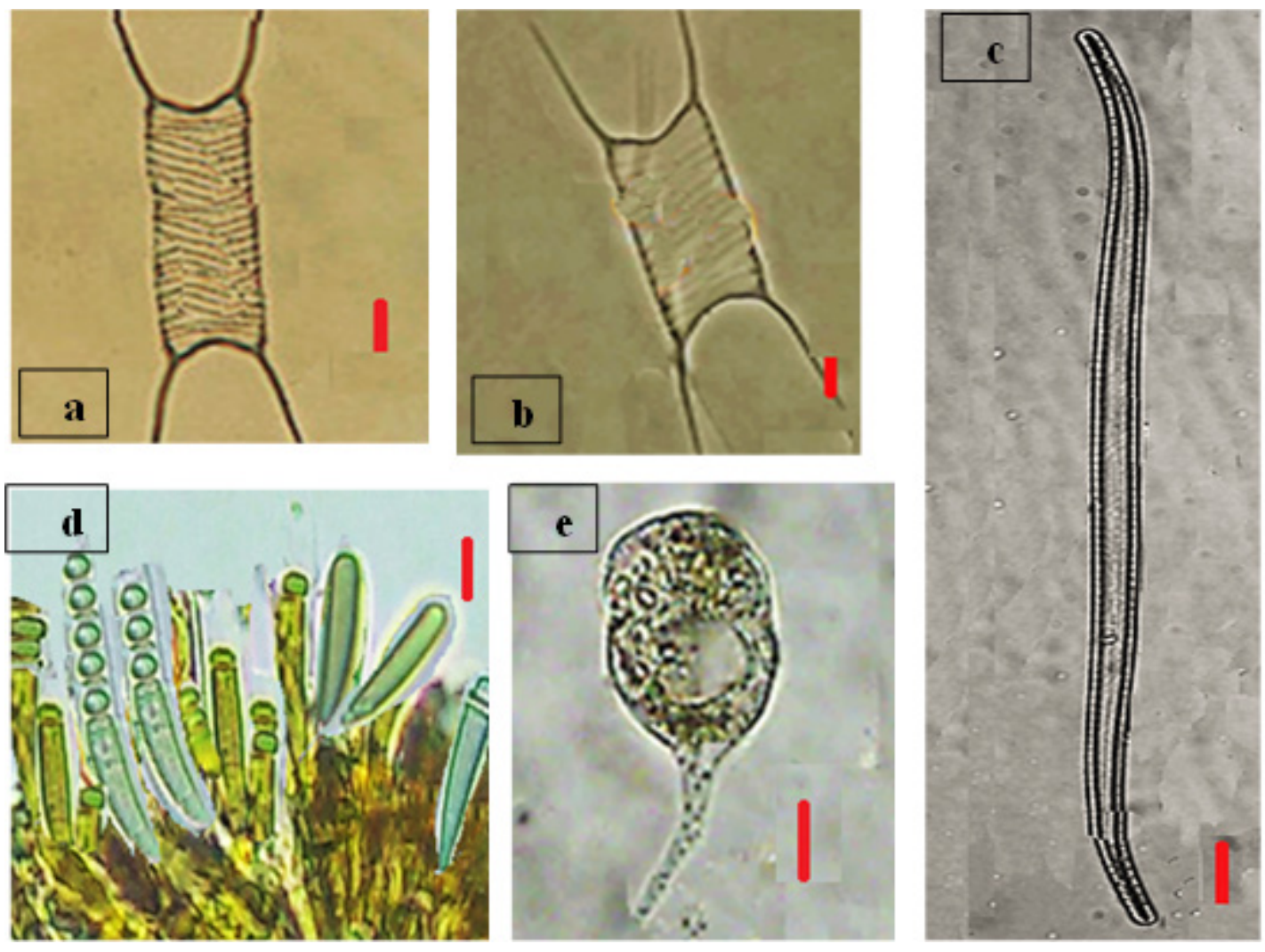

Figure 3 Types of identified algal species (a, b: Acanthoceras zachariasii; c: Stenopterobia intermedia; d, e: Stichosiphon sansibaricus; f: Phacus orbicularis (Red scale bar $=10 \mu \mathrm{m}$ )

It is clear that the maximum variety of green algae occurs during the spring months March-May due to the availability of suitable environmental conditions, like the temperature of the weather. This agrees with Tas et al. [37] in Cernek Lake in Turkey, which may be due to their preference for moderate temperatures, as has been found by other studies [12]. Staurodesmus cuspidatus appeared in location 1 $(\mathrm{pH} 7.22)$, which was considered the lowest $\mathrm{pH}$ among other locations, while Stichosiphon sansibaricus appeared in summer season (June), which may be returned to increased temperature of water, as mentioned by Hossain et al. [38] who reported that Cyanophyta had a positive correlation with the temperature of water in Nursery Lake in Bangladesh. Also, Phacus anacoelus var. unddulata appeared in June and agreed with Ganai and Parveen [39]. However, Bacillariophyta (Stenopterobia intermedia and Acanthoceras zachariasii) appeared in January and February (winter season), which agrees with the negative correlation between these algae and the temperature of water [40]. 
http://wjst.wu.ac.th

\section{Conclusions}

From the results of this work, it can be concluded that the presence of phytoplankton, whether qualitative or quantitative, reflected the status of the water quality of the Euphrates River, and whether it is suitable for the required living conditions of many species of organisms. New algal species recorded in this study were not identified in any other Iraqi studies. About 13 species belonging to phytoplankton were identified. The environment of the Euphrates River in Iraq needs more study, in order to record new species if they are present. The presence of these new microalgal for the first time in Iraqi freshwater in the Upper Euphrates River confirms somewhat the cleanliness of the water to some extent in this area. These results were declared by the physicochemical properties of water, which conformed to the specifications of Iraqi river water.

\section{Acknowledgements}

The authors appreciate and are grateful to the Dean of the College of Basic Education Modern, University of Anbar, and to all the staff members of the Department of Biology for working and providing necessary laboratory facilities and sample analysis. Also, the authors would like to thank Dr. Adeeb Abdul Jabbar, Research Center Upper Euphrates, in the University of Anbar, and Mr. Ahmed Aidan Al-Hussieny, Ministry of Science and Technology, for supporting this research.

\section{References}

[1] CJ Vörösmarty, P McIntyre, MO Gessner, D Dudgeon, A Prusevich, P Green, S Glidden, SE Bunn, CA Sullivan and CR Liermann. Global threats to human water security and river biodiversity. Nature, 2010; 467, 555-61.

[2] L Vander. Water Resources of the World. New York, USA, 1975.

[3] GW Prescott. Algae of the Western Great Lakes Area. William, C. Brown, Dubuque, Iowa, 1982, p. 977.

[4] S Ghosh, S Barinova and JP Keshri. Diversity and seasonal variation of phytoplankton community in the Santragachi Lake, West Bengal, India. Q. Sci. Connect 2012; 3, 1-19.

[5] E Acs, K Szabo, B Toth and KT Kiss. Investigation of Benthic algae communities, Especially Diatoms of some Hungarian streams in connection with Reference condition of the water Frame work Directives. Acta Botanica Hungarica 2004; 46, 255-77.

[6] S Shrestha, SK Rai and MR Dhakal. Algae of Itahari municipality and its adjoining area. Int. J. Appl. Sci. Biotechnol. 2013; 1, 5-10.

[7] LP Dalal and RS Nisal. Diversity of fresh water algae of the Mahakali Dam (Wardha, Maharashtra, India). Asiatic J. Biotechnol. Resour. 2012; 3, 1479-82.

[8] MM Al-Mahdawi and HA Ali. Fifteen new records for freshwater algae of Iraq. J. Ecol. Saf. 2014; 8, 574-82.

[9] HA Ali and MM Al-Mahdawi. Phytoplankton diversity and pollution index in North Part of Euphrates River, Iraq. Iraqi J. Sci. 2015; 56, 2223-36.

[10] FH Aziz and AQ Muhammed. Twenty new records of algae in some springs around Safeen Mountain Area. J. Adv. Lab. Res. Biol. 2016; 7, 79-85.

[11] AA Al-Hussieny. Recordind of new algal species within the Euphrates River Environment in Iraq. Int. J. Sci. Nat. 2017; 8, 1-6.

[12] FH Hassan, WD Taylor, MS Al-Taee, HJ Al-Fatlawi. Phytoplankton composition of Euphrates river in Al-Hindiya barrage and Kifil city region of Iraq. J. Environ. Bio. 2010; 31, 343-50.

[13] HAA Aldaraji. 2012, Use of Phytoplankton as Biological Indicators in Effect Assessment of AlSora-Al-Sofia Drainage Canal in Euphrates Water Quality Estern of Ramady. Master Thesis, College of Education for Women, University of Anbar, Iraq.

[14] HAAS Al-Gaff. 2015, Impact of Hadithah Dam and Some Pollution Sources on Phytoplankton Community Composition and its Environment in Northern part of Euphrates River, Al-Anbar Province. Ph.D. Thesis. College of Science. University of Anbar, Iraq, p. 174. 
http://wjst.wu.ac.th

[15] APHA, American Public Health Association. Standard Methods for the Examination of Water and Wastewater. $21^{\text {st }}$ ed. Washington, DC, 2005, p. 22621.

[16] JM Salman, F Hassan and MA Baiee. Practical methods in environmental and pollution laboratory. Environmental Research and Studies Center, University of Babylon, Iraq, 2017, p. 144.

[17] RAM Hadi. 1981, Algal Studies of the River USK. Ph.D. Thesis, University of Cardiff. College Cardiff. P. 364.

[18] TV Desikachary. Cyanophyta. Indian Council of Agricultural Research. India, 1959.

[19] GM Smith. The Fresh Water Algae of the United States. $2^{\text {nd }}$ ed. McGraw Hill, New York, 1950, p. 719.

[20] GW Prescott. How to Know the Fresh Water. $3^{\text {rd }}$ ed. Williame Brown, Dubuque, Iowa, 1979, p. 348.

[21] GCF Hinton and BK Moulood. Some Diatoms Brackish Water Habitats in Southern Iraq. Nova Hedwigia 1980; 31, 436-47.

[22] JP Wehr and RG Sheath. Fresh water algae of North America: Ecology and Classification. Elsevier Science, USA, 2003, p. 935.

[23] BK Maulood and JJ Toma. Checklist of Algae in Iraq. J. Bob. Univ. C: Pure Appl. Sci. 2004; 9, 117.

[24] RA Hadi, AM Ismail and AH Talib. Check List of the algae in Diyala River, Iraq. Um-Salama Sci. J. 2009; 6, 329-45.

[25] KM Bahram, FM Hassan, AA Al-Lami, JJ Toma and AM Ismail. Checklist of Algal Flora in Iraq. Republic of Iraq, Ministry of Environment, 2013, p. 94.

[26] SA Shehata, SA Badr, GH Ali, MM Ghazy, AK Moawad and SZ Wahba. Assessment of Nile water quality via phytoplankton changes and toxicity bioassay test. J. Appl. Sci. Res. 2009; 5, 2083-95.

[27] HA AL-Saadi, TI Kassim and AA AL-lami. Spatial and seasonal variation of phytoplankton population in the upper region of the Euphrates River. Iraq. Limnologica 2000; 30, 83-90.

[28] FM Hassan, NF Kathim and FH Hussein. Effect of chemical and chemical properties of River water in shatt Al-Hilla on phytoplankton communities. E-Journal Chem. 2008; 5, 323-30.

[29] JM Salman, HJ Jawad, AJ Nassar and FM Hassan. A study of phytoplankton communities and related environmental factors in Euphrates river (between two cities: Al-Musayyab and Hindiya, Iraq. J. Env. Pro. 2013; 4, 1071-9.

[30] AM Rabee. Biodiversity of Rotifera and Cladocera in the upper region of Euphrates River-Iraq. Baghdad Sci. J. 2007; 4, 221-32.

[31] GK Reid. Ecology of Inland Waters and Estuaries. Van Nostrand Rein, New York, 1961, p. 375.

[32] YA AL-Gahwari. 2003, Use of Phytoplankton Abundance and Species Diversity for Monitoring Coastal Water Quality. Master Thesis, College of Science. University of Sains Malaysia, Malaysia.

[33] PS Giller and B Malmqoist. The Biology of Stream and Rivers. New York Oxford University Press, 1998, p. 296.

[34] NL Çiçek and F Yamuc. Using epilithic algae assemblages to assess water quality in Lake Kovada and Kovada Channel (Turkey), and in relation to environmental factors. Turkish J. Fish. Aquat. Sci. 2017; 17, 701-11.

[35] A Al Bomola. Temporal and Spatial Changes in Water Quality of the Euphrates River-Iraq. Sheet TVVR-11/5013. Division of Water Resources Engineering, Lund University, 2011, p. 135.

[36] YP Li, CY Tang, ZB Yu and K Acharya. Correlations between algae and water quality: factors driving eutrophication in Lake Taihu, China. Int. J. Environ. Sci. Tech. 2014; 11, 169-82.

[37] BI Tas, A Gonulol and E Tas. A study on the seasonal variation of the phytoplankton of lake Cernek (Samsun-Turkey). Turkish J. Fish. Aquat. Sci. 2002; 2, 121-8.

[38] MI Hossain, MM Alam, MMB Kamal, SM Galib. Investigation of phytoplankton and physicochemical parameters in nursery, grow out and brood stock ponds. J. Sci. Res. 2013; 5, 555-71.

[39] HA Ganai and S Parveen. Effect of physico-chemical conditions on the structure and composition of the phytoplankton community in Wular Lake at Lankrishipora Kashmir. J. Biodivers. Conservat. 2014; 6, 71-84.

[40] M Das and T Panda. Water quality and phytoplankton population in Sewage Fed River of Mahanadi, Orissa, India. J. Life Sci. 2010; 2, 81-5. 